\title{
Ivana Čagalj
}

Šlesko sveučilište u Katowicama

ivana.cagalj87@gmail.com

(iD https://orcid.org/0000-0002-3016-9144

\section{Imota ili „život na rubu“ u odabranim djelima Petra Gudelja}

Sažetak: U radu se daje prikaz Imotske krajine, tzv. Imote, kao mitskoga zavičaja u odabranim pjesničkim i proznim djelima Petra Gudelja. Koncept periferije razmotrit će se s jedne strane u geografskom položaju navedenoga područja i društveno-političkom ,životu na rubu“ te njegovoj refleksiji u književnim djelima, dok će se s druge strane periferija prepoznati i u dugogodišnjoj marginaliziranosti Gudelja na hrvatskoj književnoj sceni te u elementima njegove poetike „samorodnosti“, ali i oslanjanju na tradiciju i usmenu književnost. Analiza će pokazati koliko su kontroverze i kontrast krške periferije plodno tlo za (nado)gradnju (književnoga) identiteta.

Ključne riječi: Imota, krajina, identitet, usmena književnost, mitizacija

\section{Uvod}

Petar Gudelj, hrvatski književnik, antologičar i proučavatelj hrvatske i susjednih književnosti, koji je dio najplodnijih godina proveo izvan matične književnosti, na hrvatskoj književnoj sceni još uvijek nije dovoljno prepoznat, što zbog odsustva s te scene, što zbog samotnjaštva i povlačenja, a dijelom i zbog tzv. ,samorodne“ poetike. Stvaralaštvo i život ovoga književnika samotnjaka pogodni su za analizu koncepta periferije na više razina. Stoga ćemo taj koncept razmotriti u odnosu na geografsko-povijesno-društvene specifičnosti Imotske krajine, književnikova zavičaja; na drugoj razini razmotrit ćemo značajke Gudeljeve poetike i vidjeti koliko namjerno bira, a koliko neizbježno pod utjecajem genius loci više od pola stoljeća stvara djela za koja bi se 
moglo reći da ostaju rubna u temama i stilu; na ovo ćemo se nadovezati nezaobilaznom temom dugogodišnje marginalizacije autora koji pripada skupini „,izmeđnika“ i najvećih nepoznatih hrvatskih pjesnika.

Iz opusa ovoga plodnog autora odabrali smo za analizu novije zbirke pjesama i pjesničke proze: Imotska knjiga (2017), Sve što si donio iz planine (2012), Duša tilu (2010), Zmija mladoženja (2007) i Pelazg na mazgi (2004) te lirske monografije Put u Imotu (1997) i Moja Imota (1991).

\section{Periferija u geografsko-povijesnom sloju}

Imotska je krajina u 26 dosad objavljenih Gudeljevih knjiga - od prve zbirke Ruke, suze i čempresi (1956) do najnovije Imotske knjige (2017) - prikazana kao prostor dosta širi od $650 \mathrm{~km}^{2}$ koje zauzima ovo područje sastavljeno od sela koja konvergiraju gradu Imotskome kao centru. I u stihovima i u prozi Gudelj će nerijetko umjesto riječi krajina, kao ono što je na kraju, na rubu, uporabiti pojam Imota. ${ }^{1}$ Tako primjerice u Imotskoj knjizi ponavlja ono što je u ranijim knjigama zapisao: „Valja Imoti vratiti njezino prvo, pravo ime“, 2 imajući na umu povijesnu Imotu onako kako ju opisuje Glibota:

Imotska krajina je u prošlosti u svoj sastav uključivala šire područje negoli danas. Pridruženi su joj bili veći dijelovi bosanskohercegovačkih općina Grude, Posušje i Duvno danas nazivani Gornja i Donja Bekija. Naziv Bekija nastao je iz turske riječi bekiye, bakiye što na hrvatskom jeziku znači ostatak. Ovi dijelovi su izdvojeni iz Imotske krajine razgraničenjem iza Požarevačkog mira, koji je sklopljen u Požarevcu 21. srpnja 1718. godine. Gornja i Donja Bekija bili su sastavni dijelovi starohrvatske župe Imota, a ne kako se smatralo samo sastavni dijelovi kadiluka Imotski,

\footnotetext{
${ }^{1}$ Imota (lat. Emotha) starohrvatska je župa sa središtem u Imotskom; danas obuhvaća 24 župe Imotske krajine (ukupne površine oko $650 \mathrm{~km}^{2}$ s oko 30000 stanovnika), dok su hercegovačke župe nakon 1718. ostale izvan Imote. Administrativno je podijeljena na grad Imotski i 8 općina, odnosno 44 naselja [usp. Milan Glibota, „Prijedlozi o promjeni granica uoči austrougarske okupacije BiH 1878. g.," Imotske novine, god. 1, br. 1 (2004), pristupljeno 28. siječnja 2020., http://www.modrojezero.org/docs/history/granice.html; Jozo Grbavac, Povijest, vjera i kulturna baština u Imoti (Zagreb: Školska knjiga, 2017); Andrija Nikić, „Oslobođenje Imotske krajine od Turaka,“ 16. 6. 2005., pristupljeno 1. ožujka 2020., https://povijest.blogspot. com/2005/06/prof-fra-andrija-niki-osloboenje.html; Silvestar Kutleša, Život i običaji u Imockoj krajini (Imotski: Matica hrvatska; Hrvatska akadamija znanosti i umjetnosti, 1993)].

${ }^{2}$ Petar Gudelj, Imotska knjiga (Zagreb: Školska knjiga, 2017), 454.
} 
koji je u sebe svojedobno uključivao nahije: Imota, Duvno, Buško Blato, Ljubuški, Posušje, Gorsku župu, Fragustin i Primorje. ${ }^{3}$

U kombinaciji poetskog eseja ${ }^{4}$ fantastične turističke monografije objavljene pod nazivom Moja Imota (1991) kao i u kombinaciji monografije i putopisa pod nazivom Put u Imotu (1997) Gudelj Imotsku krajinu čvrsto povijesno i geografski veže uz susjednu Hercegovinu, pri čemu je bitno naglasiti kako je takvo kroničarsko-lirsko razmatranje izraslo na negodovanju na spomenutu promjenu granice prisutnu u njegovih zemljaka, lokalnoga stanovništva, ali i predstavnika inteligencije. Tako će fra Vjeko Vrčić, poznati istraživač i arhivist povijesti Imotske krajine, potvrditi nezadovoljstvo u narodu koje se generacijama prenosilo, od tog kobnog trenutka kada je zapadni dio tzv. nahije došao pod katoličku, mletačku vlast te je prozvan „Acquisti novissimo“" je istočni dio ostao pod muslimanskom vlasti usprkos očekivanjima katoličkog stanovništva u Hercegovini da će mletačka vojska nakon osvajanja Imotskoga osloboditi i Hercegovinu. ${ }^{6}$ Jedan od Vrčićevih nasljednika fra Jozo Grbavac također će potvrditi kako je u narodu podjela imotsko-bekijskoga polja viđena kao prisilna i umjetna, što je pogodovalo nastanku mita o ,postojanju iste krvi, istoga sunca, istoga jezika, zajedničke povijesti i povijesnog sjećanja, iste kulture i istoga mentaliteta“.7 Gudelj će istu misao ovako iznijeti: „...Hercegovina. Toj zemlji Imotska krajina pripadala tijekom stoljeća, a po zemlji, vodi, suncu i krvi - pripada i danas.“8

Širina pojma Imote vidi se i u sljedećim stihovima koji upućuju na otvorenost, na povoljan prometni položaj ove krajine, zbog čega je ona dugo imala vojni i politički značaj: „Ima Imota sedmera vrata. Vrata od Neretve. Vrata od Cetine. Vrata od Bosne. Vrata od mora. Vrata od neba. Vrata od zemlje. I vrata od matere. Na sedmera vrata dođe i prođe sve imotsko."9

\footnotetext{
${ }^{3}$ Glibota, „Prijedlozi o promjeni granica.“

${ }^{4}$ Usp. Tea-Tereza Vidović Schreiber, Mitski med riječi (Split: Hrvatsko kulturno društvo Napredak, 2005), 16.

${ }^{5}$ Fra Vjeko Vrčić, „Povijest franjevačkog samostana i crkve svetog Franje u Imotskom,“ u Čuvari baštine. Zbornik radova simpozija u prigodi 250. obljetnice prijenosa franjevačkoga samostana u grad Imotski, ur. Marko Babić, Bruno Pezo (Imotski: Franjevački samostan; Makarska: Služba Božja, 1989), 66.

${ }^{6}$ Dr. fra Andrija Nikić, „Oslobođenje Imotske krajine od Turaka,“ u Čuvari baštine, 179.

${ }^{7}$ Grbavac, Povijest, vjera, 71.

${ }^{8}$ Petar Gudelj, Moja Imota (Zagreb: Privredni vjesnik, 1991), 40.

${ }^{9}$ Gudelj, Imotska knjiga, 9.
} 
Uz veze s Hercegovinom, koje su se povijesno gledano odvijale preko odnosa imotskoga svećenstva $\mathrm{s}$ braćom franjevcima preko granice, ${ }^{10}$ Imota je bila otvorena $i$ prema jugu i zapadu. U tom kontekstu možemo istaknuti da je uoči 1861. imotska pretura pripadala splitskom okrugu, a 1868. Imotski je formiran kao jedan od ukupno 12 dalmatinskih kotara. ${ }^{11}$ Nadalje, 1922. Imotska je krajina nakratko pripojena Dubrovačkoj, a zatim Splitskoj oblasti. ${ }^{12}$ Pod vodstvom svojeg zastupnika u Dalmatinskom saboru i hrvatskog preporoditelja don Mihovila Pavlinovića, ${ }^{13}$ a usprkos autonomašima, Imoćani su se vidjeli kao dio Dalmacije, a Dalmaciju kao dio Hrvatske. Žustro će se boriti protiv predstavnika unitarizma te će u Krajini veliku popularnost uživati Hrvatska (republikanska) seljačka stranka Stjepana Radića, ${ }^{14}$ čime će Imota zaslužiti naziv „Radićeve kule“. ${ }^{15}$ Ovakav će prohrvatski stav naglašavati i Gudelj ističući hrvatstvo Imote u različitim književnim vrstama, od lirskih pjesama preko žanrovskih kombinacija crtica, anegdota, pjesama u prozi, putopisa, kronika.

S jedne strane, Gudelj krajinu prikazuje kao nešto široko i otvoreno, kao granicu zapada i istoka, spoj Mediterana i Balkana, otvoren hrvatskim i globalnim tijekovima u književnom i izvanknjiževnom smislu, kao izniman primjer dijela Hrvatske koji je tijekom povijesti rabio sva tri hrvatska pisma, glagoljicu, ćirilicu i latinicu, te se služio raznim jezicima, počevši od ilirskog, latinskog, staroslavenskog. ${ }^{16} \mathrm{~S}$ druge strane, Imota ostaje sasvim autonoman i jedinstven prostor zbog burne povijesti, krške geografije, smještenosti na rubu različitih državnih tvorevina u kojima se nalazila, žilavosti stanovnika, naklonjenosti oralnoj tradiciji, folkloru. Sam naziv krajina zadržao se iz vremena austrijske uprave kad je stanovništvo bilo organizirano na vojnički način u krajine ${ }^{17}$ te se krajina kod Gudelja doživljava kao „uvijek periferna, najčešće bezimena“" ${ }^{18}$ kao okrajak prema nečemu, kao područje koje je prepušteno samo sebi, borbi za opstanak, jer je kao i ostali dijelovi Dalmatinske

\footnotetext{
${ }^{10}$ Mr. fra Josip Grbavac, „Uloga svećenstva Imotske krajine u narodnom preporodu,“ u $\breve{C} u$ vari baštine, 208.

${ }^{11}$ Mr. fra Josip Grbavac, „Uloga svećenstva,“ u Čuvari baštine, 206.

${ }_{12}$ Ante Ujević, Imotska krajina (Imotski: MH, 1991), 288.

${ }^{13}$ Zanimljivo je napomenuti da je don Mihovil Pavlinović imotskih korijena, prema: Ujević, Imotska krajina, 270.

${ }^{14}$ Ujević, Imotska krajina, 292.

${ }^{15}$ Grbavac, Povijest, vjera, 106.

${ }^{16}$ Gudelj, Moja Imota, 173.

${ }^{17}$ Dr. fra Vicko Kapitanović, „Imotska krajina u vrijeme francuske uprave,“ u Čuvari baštine, 191.

${ }^{18}$ Gudelj, Moja Imota, 39.
} 
zagore kroz povijest bila nerijetko zanemarena, „kao i da ne opstoji na krugu zemaljskom il da je Krajina izvan Pokrajine i prosvjetljene Države“" 19

Desetljećima gradeći na papiru imotski imaginarij, Gudelj će povijesne činjenice nadograđivati na neotradicionalističku misaonu podlogu te će se pri portretiranju Imoćana često opirati o stereotipe, ističući trijadu oštroumlje, radoljublje i rodoljublje. ${ }^{20} \mathrm{U}$ ranije spomenutim monografijama kao i u zbirci Imotska knjiga (2017) u kojoj donosi i presjek ranije objavljenih djela koja se ne mogu svrstati pod jedan žanrovski nazivnik, Gudelj Imoćane predstavlja kao snalažljive ljude koji su kroz burnu povijest očuvali temeljne ljudske vrijednosti, ljude s krša koji su generacijama odrastali u oskudici, ekonomskoj i prirodnoj, pa su zbog toga i razvili bogat unutrašnji lirsko-epski svijet. Gudelj će ustvrditi: „Ne bi pokoljenja bez pokolja.“21 Prirodne karakteristike krške krajine, česta smjena vlasti ${ }^{22}$ razlogom su žilavosti povijesne Imote. Takve su okolnosti dovele do stvaranja stereotipa o sklonosti Imoćana različitim prevarama pri trgovini, švercanju (posebno duhana), o odlasku na zapad kad god nastupe teške prilike, redovito u Njemačku kao gastarbajteri ili Austriju kao galantari, pritom uvijek ističući veliko hrvatstvo i lokalpatriotizam. Srijedom je stanovnicima Imote dopušteno griješiti na ,pazaru“, nedjeljom se ispovijedaju ${ }^{23}$ jer, kako Gudelj kaže, „Ma koliko neobuzdana i neukrotiva, poskočka i satirska, Imota je kršćanska.“24 Još je jedan kontrast zanimljiv i na njega će autor upozoriti, naime Imotska je krajina statistički jedna od najnerazvijenih u Hrvatskoj s nekada visokom stopom nepismenosti ${ }^{25}$,

\footnotetext{
${ }^{19}$ Krešimir Kužić, Povijest Dalmatinske zagore (Split: Književni krug, 1997), 275.

${ }^{20}$ Gudelj, Moja Imota, 10.

${ }^{21}$ Gudelj, Imotska knjiga, 42.

${ }^{22}$ Doba hrvatskih narodnih vladara, od 1102. u zajednici s Mađarskom, pod oblasti Zahumlja (Huma), od 1326. dijelom Bosne za vrijeme Stjepana II. Kotromanića, zatim smjena bosanskih te hrvatsko-ugarskih vladara, 1493. pada pod tursku vlast koju 1717. zamjenjuje mletačkom, potom austrijskom od 1797. do 1918., uz kratkotrajnu francusku (Napoleonovu) upravu od 1806. do 1813., te se od 1918. nalazi u Kraljevini SHS, od 1939. do 1941. u sastavu je Banovine Hrvatske, zatim u sastavu NDH od 1941., u sastavu SFRJ od 1945. do 1991., otkad je dijelom RH (usp. Nikić, „Oslobođenje Imotske krajine“; Ujević, Imotska krajina).

${ }^{23}$ Gudelj, Moja Imota, 100.

${ }^{24}$ Gudelj, Imotska knjiga, 74.

${ }^{25}$ Usp. Ujević, Imotska krajina, 37; 248. Prema njegovim podatcima, godine 1798. nepismenost je viša od $99 \%$, a 1807. iznosi oko $97 \%$. Do 1971. nepismenost se spustila na $15,71 \%$, a danas je u skladu s hrvatskim prosjekom $0,8 \%$ (izračun u okviru podataka za Splitsko-dalmatinsku županiju). Izvor: „Stanovništvo staro 10 i više godina prema spolu, a nepismeni i prema starosti, popis 2011.,“ pristupljeno 17. rujna 2019., https://www.dzs.hr/ Hrv/censuses/census2011/results/htm/h01_01_33/H01_01_33.htm1.
} 
a danas nezaposlenosti ${ }^{26}$, dok vanjska slika ljudi, kuća, automobila pokazuje sasvim suprotno. Većina je toga sponzorirana iz dijaspore, kamo Imoćani u valovima odlaze. ${ }^{27}$

Što se posljednjeg pojma iz trijade tiče, Imota je predstavljena kao rodoljubni kraj još od doba narodnih vladara. Tu se Gudelj poziva na mit o krunjenju prvoga hrvatskoga kralja Tomislava na Duvanjskom polju, ${ }^{28}$ o čemu piše i pop Dukljanin, a što potvrđuje spomenute veze Imote sa susjednom Bosnom i Hercegovinom. Česta smjena vlasti uz jaku monokulturalnost ${ }^{29}$ rezultirala je potrebom za (re)afirmacijom identiteta i snažnom željom za hrvatskom neovisnošću koja seže sve do te točke da su Imoćani mahom prihvatili Pavelićevu politiku te ih je on sam prozvao ,ustaškom kulom,“30 a od samostalnosti Hrvatske do danas samostalnosti do danas očita je prodešnjačka politika. Fakti kažu da je od nešto više od 500 prvih ustaških emigranata interniranih u Italiji oko 125 rođeno u Hercegovini, a oko 160 bili su Imoćani. Zbog toga je Imota često trpjela teror tadašnjih vlasti te se tješnje povezala geopolitički, gospodarski i psihološki s Hercegovinom u jednu cjelinu. ${ }^{31}$ Vojnopolitička aktivnost Imote ipak je sezala ranije od spomenutoga rata, naime Imota je bila vojnička župa sa svojim posjedima, djelatnicima, čak i posebnom crkvom, a prestala je postojati 1816. nestankom vojske u Imotskom. ${ }^{32}$

Gudeljeva Imota tako ostaje prostor prepun kontrasta: ona je $u$ isti mah kamen, krš, škrta zemlja, vojnička kula, ali i prometno čvorište,

\footnotetext{
${ }^{26}$ Prema podatcima Državnoga zavoda za statistiku i Hrvatskoga zavoda za zapošljavanje za 2011. godinu (prije novog vala iseljavanja) grad Imotski imao je 10764 stanovnika, od kojih čak 3946 nezaposlenih, čime je drugi grad po nezaposlenosti u Splitsko-dalmatinskoj županiji, odmah iza Splita. Nezaposlenost se očituje i u dotad najjačem sektoru, građevinarstvu. Godine 2017. nezaposlenost u Imotskom iznosila je 9,9 \%, čime je i dalje drugi na listi. Izvor: „Izvješće o nezaposlenosti i zapošljavanju u 2017. godini u Splitsko-dalmatinskoj županiji,“" pristupljeno 17. 9. 2019., http://www.hzz.hr/UserDocsImages/ST_Godisnjak_2017. pdf.

${ }^{27}$ Gudelj, Moja Imota, 112.

${ }^{28}$ Gudelj, Moja Imota, 39.

${ }^{29}$ Monokulturalnost stanovništva pokazuju statistike; prema podatcima Državnoga zavoda za statistiku za 2011. godinu Imotski ima 96,78 \% Hrvata i 96,17 \% katolika. Izvor: „Stanovništvo prema vjeri po gradovima/općinama, popis 2011.," pristupljeno 17. rujna 2019., https:// www.dzs.hr/Hrv_Eng/publication/2012/SI-1469.pdf.

${ }^{30}$ Gudelj, Moja Imota, 175.

${ }^{31}$ Šimun Šito Ćorić, Hercegovci, Hrvati Hercegovine, mitovi, predrasude, zbilja (Zagreb: Pegaz, 1995), 113.

${ }^{32}$ Fra Vjeko Vrčić, „Zanimljiv zapis iz starije naše povijesti (Iz ostavštine fra Šimuna Gudelja),“ u Fra Vjekin vijek (zapisi o prošlosti i životu ljudi Imotske krajine), ur. Bože Ujević (Imotski: KUD „Ujević“, 2013), 27.
} 
vrata između dvaju svjetova, prostor bogat podzemnicama i ljekovitim travama, Imota je tvrdoglava, monokulturalna, žilava, tradicionalna, ali i otvorena prema Hrvatskoj i Europi. Imota je krajina, periferija, ali s nagnućem prema centru, koji je za nju u prošlosti, Gudeljevim riječima, više bio Dubrovnik, negoli današnji Zagreb. ${ }^{33}$

\section{Periferija u tematsko-stilskom sloju}

$\mathrm{Na}$ drugoj razini razmotrit će se koncept periferije u tematskostilskom sloju Gudeljevih djela. Autorova poetika nerijetko se naslanja na tradiciju i na usmenu književnost, koja cvjeta u krškim krajinama, poput onih koje su iznjedrile primjerice Filipa Grabovca ili Andriju Kačića Miošića. Ovakvu poetiku odlikuje inzistiranje na motivima koji karakteriziraju život na rubu. Balkansko-mediteranski motivi opisuju perifernu Zagoru, i kao da ih ima ograničen broj, autor kao da jezično škrtari, neprestano se vraćajući motivima zemlje, jezika, tijela, (ne) plodnosti krša (meda, kadulje, jastreba, zmije, vuka i sl.). U stvaranju dugom više desetljeća Gudelj reducira jezik, ne mareći za stilske postupke tipične za određena razdoblja, pa u tom smislu možemo reći da kod njega nema napretka i nema praćenja dominantnih književnih struja. On ostaje vjeran sebi. Takva oskudica jezika vjerojatno je pod utjecajem genius loci, oskudice krša iz kojega potječe, gdje se ni riječi ni plodovi prirode ne dijele olako, što im daje dodatnu vrijednost. Kondenziran izraz zajedno s form(ul)ama tipičnim za usmenu književnost kao što su primjerice bajalice podcrtava magijsku moć jezika pomoću mnemotehničke i ritualne funkcije ponavljanja ${ }^{34}$ :

Neka po mojoj zemlji

zaigra tvoja zemlja

Neka po mom jeziku

zaigra tvoj jezik

Neka po mojoj krvi

zaigra tvoja krv

\footnotetext{
${ }^{33}$ Gudelj, Moja Imota, 71. O vezama s Dubrovnikom, između ostaloga, svjedoče podatci o dolasku dubrovačkih učitelja na rad u Imotsku krajinu još od 1907., dok imotski studenti pohađaju Učiteljsku školu u Dubrovniku, a imotska samostanska biblioteka posjeduje dragocjeni prijepis Gundulićeva Osmana iz 1769. (Vidi: Ujević, Fra Vjekin vijek, 124-125).

${ }^{34}$ Petar Gudelj, Pelazg na mazgi (Zagreb: Školska knjiga, 2004), 201.
} 
U motivima, temama i stilu, Imotska je krajina uzdignuta na razinu mitskoga, pri čemu se Gudelj služi trima vrstama mita. On, naime, uzima priče iz tradicije vlastite i drugih kultura (drevni mitovi) koje potom stavlja u suvremeni kontekst kako bi se obratio „svijesti naroda“, svijesti čitatelja, „izazivajući duboke osjećaje“ (moderni mitovi) i stvarajući osobne mikromitove, odnosno pokušavajući objasniti, ali i otvoriti pitanja, najčešće ona identitetska. Navedene tri vrste mita nisu razgraničene ni u pojedinim uradcima ni gledajući sveukupnost Gudeljeva stvaralaštva. Radi se prije o mehanizmu transponiranja, odnosno premještanja jednih mitova u druge.

Jedan od razloga mitizacije jest svakako individualno iskustvo autora, mijenjanje boravišta, nostalgija za zavičajem, uspomene na djetinjstvo. Stvaralaštvom i životom ovaj autor spaja matičnu državu sa susjednom Bosnom i Hercegovinom te Srbijom. Rođen je 1933. u selu Podosoje koje pripada Imotskoj krajini, školovao se u Imotskom, Mostaru i Beogradu, kamo odlazi 1955. te ostaje 35 godina, da bi se 1991. vratio u Bašku Vodu, gdje i danas živi. Drugim riječima, imotsko-hercegovačku periferiju bogatu usmenom književnošću, sklonu mitovima, legendama, predajama, Gudelj mijenja centrom „svetosavko-bizantske kulture i civilizacije, gdje prisutna iracionalna i mitomanska svijest sve stvarno pretvara u nestvarno, a predodžbu svijeta gradi na temeljima narodnih pjesama i mitskih predanja. ${ }^{\text {"35 }}$ Geografsko-povijesni prostor i periferije i centra u kojem autor stvara plodno je tlo za razvoj kolektivnih mitova, ali ono po čemu je Gudeljevo stvaralaštvo posebno jest njegova osobna rekreacija postojećih mitoloških narativa motivirana traganjem za fiksnom točkom, nepromjenjivošću koja je suprotstavljena konačnosti vlastite egzistencije.

Gudelj mitove drevnih kultura inkorporira u svoje stihove i prozne uratke vezujući ih uz osobna iskustva i povijesne činjenice: „Iz mita

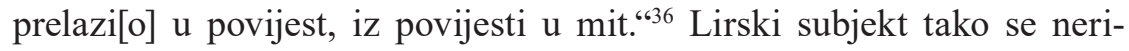
jetko pretače u mitološke junake ili u floru i faunu mediteransko-balkanskog areala. Ovaj mehanizam premještanja iz doba antike do doba kralja Tomislava, ili pak iz doba djetinjstva do doba Domovinskoga rata čest je u Gudeljevu stvaralaštvu. Tako će pjesme nasloviti „Ahil u Runovićima“, ${ }^{37}$ „Bogovi na pikniku u Ričicama“ ${ }^{38}$ „Dijana voljela

\footnotetext{
${ }^{35}$ Vidović Schreiber, Mitski med riječi, 12.

${ }^{36}$ Petar Gudelj, Duša tilu (Zagreb: V.B.Z., 2010), 230.

${ }^{37}$ Petar Gudelj, Sve što si donio iz planine (Zagreb: Školska knjiga, 2012), 78.

${ }^{38}$ Gudelj, Imotska knjiga, 32.
} 
Proložac". ${ }^{39}$ U drugim će djelima kao glavni motiv uzeti zmiju u onom značenju koje ona dobiva u hrvatskim narodnim pričama, ali i drevnim (antičkim, indijskim, biblijskim) mitovima. Upravo taj mehanizam ono je po čemu Gudeljevu poeziju zovemo samorodnom ili ujevićevski sebeznalom. ${ }^{40}$ Kako sam autor kaže: „To sam ja sam pisao hrvatsku poeziju: kao da je prije mene, kao da je osim mene nije pisao i ne piše nitko. ${ }^{(41}$

Uz mit, autor se inspirira i drugim oblicima usmene književnosti kao što su legende, predaje, poslovice, prevrednuje ih, nadopunjuje, dajući im dodatna značenja. Čitatelj ima osjećaj da se ispreda jedna pjesma, varirana kroz vrijeme i prostor, čime se stvara osjećaj povjerenja u pjesnički, bardski glas.

Periferija u tematsko-motivskom sloju očituje se autorovom zaokupljenošću identitetskim pitanjima, dinamičnim odnosom zemlje i domovine, čovjeka, pejzaža i jezika. Periferija kao da lirskoga subjekta neprestano tjera na preispitivanje odnosa prema okolini, na traganje za podrijetlom, redefiniranje identiteta sebe i svega onoga što ga okružuje. Tako lirski subjekt lebdi po imaginariju u kojem se isprepliću Grci, Iliri, Morlaci i Vlaji s imotskom svakodnevnicom.

Ovo ilustrira primjerice pjesma „Začet među kozama ${ }^{642}$ u kojoj su u tek nekoliko stihova inkorporirani motivi Grčke, Ilirije i Hrvatske; koza kao jedan od simbola krške krajine, ilirska perunika kao hrvatski nacionalni cvijet, zmija kao kontroverzan lajtmotiv, kao zavodnica, ali i učiteljica, čiji rašljast jezik upućuje na potrebu za bilingvalnošću, za istodobnim pripadanjem hrvatskoj kulturi, ali i drevnoj prošlosti:

\section{Začet među kozama. \\ [...] Tebe ću začeti u perunici. \\ [...] Začet ću te u zmiji. \\ [...] Sve dok ne progovoriš grčki iz mojih usta}

Gudelj u pogledu s ruba ne zazire ni od političkih tema, kao primjerice u zbirci Zmija mladoženja (2007), nadahnut narodnom predajom o momku koji noću svlači zmijsku košulju i pretvara se u ljepotana,

\footnotetext{
${ }^{39}$ Gudelj, Imotska knjiga, 34.

${ }^{40}$ Ivan Lovrenović, „Petar Gudelj ili znanje planine,“ Uvod u Pelazg na mazgi. Petar Gudelj (Zagreb: Školska knjiga, 2004), 11.

${ }^{41}$ Ervin Jahić, „Strah je magnetno polje u kojem drhte sve moje pjesme,“ Poezija - časopis pjesničke prakse, god. 8, br. 1-2 (2012): 35-51, pristupljeno 17. rujna 2019., https://www. ceeol.com/search/article-detail?id=118986.

${ }^{42}$ Gudelj, Pelazg na mazgi, 269.
} 
ali i lokalnim, imotskim vjerovanjem o natprirodnim moćima djeteta koje se rodi u tzv. košuljici. ${ }^{43}$ Autor će kazati da je motivom zmije htio pokazati ljudsku prijetvornost: ${ }^{44}$

Naslov „Zmija mladoženja“ nije moja izmišljotina, to je motiv iz svjetskoga folklora. Zmija koja se ljudski ponaša, pretvaranje zmije u čovjeka i obrnuto. To je vječno mjesto. Od antičkoga, grčkoga mita i ne samo grčkoga. I indijskoga, indijanskoga, asteka, maja, židovskog, biblijskog. Zmija je u osnovi čovjekovoj. I čovjek nosi u sebi zmiju, a to je njegova kralježnica, a glava nam je i zmijska i ljudska. Čovjek je zmija po karakteru i po onome što stvara, što razara. Zmija je površno gledano simbol zla, ali ona je isto toliko znak života.

Raskrinkavanje se vidi u poetskim i proznim uradcima inspiriranim događanjima u Imotskoj krajini poslije Drugoga svjetskoga rata. Uspomene iz djetinjstva, seoske priče i legende, mitski odnos s prirodom koja igra ključnu ulogu u životu stanovnika Imotske krajine čine podlogu za kritiku i raskrinkavanje društveno-političkog licemjerja. Tako se u ovoj zbirci isprepliću motivi ustaša, partizana, knojevaca, oznaša s likovima vila, vukodlaka, florom i faunom koja se u Gudeljevim metamorfozama premeće u djevojke, uskoke, vojnike. U isti mah se priroda antropomorfizira sudjelujući u društveno-političkim zbivanjima i nerijetko kontrolirajući njihov tijek, dok se ljudi pretvaraju u grabove, kobile, vukove, zmije, čak i ćulke, odnosno kamenje postavljeno u krške vinograde. Narator odnosno lirski subjekt provlači se kroz sve te likove dok se živa prisutnost autora otkriva u ispovjednu tonu, pripovijedanju u prvom licu, iznošenju autobiografskih detalja.

Mehanizam kojim se Gudelj u poeziji i prozi služi može se promatrati kao tipična karakteristika književnosti pograničja. Naime, prema Dąbrowskoj-Partyki, za književnost je pograničja karakteristično građenje umjetničkog prostora, ponavljanje motiva i stilova, specifični tip autora/naratora/junaka/lirskog subjekta, a sve u svrhu autoanalize koja treba dovesti do autentične samospoznaje i uroditi nastankom novog modela identiteta. Ovakav model alternativa je ideologičnim

\footnotetext{
${ }^{43}$ Dinka Alaupović-Gjeldum, „Običaji životnog ciklusa u Imotskoj krajini i zapadnoj Hercegovini, od konca XIX. stoljeća do Drugog svjetskog rata,“ Ethnologica Dalmatica, god. 1, br. 8 (1999): 152, pristupljeno 2. rujna 2019., https://hrcak.srce.hr/108497.

${ }^{44}$ Goran Karanović, „Petar Gudelj: Nijednu svoju pjesmu nisam napisao namjerno,“ 3. 3. 2015., pristupljeno 1. ožujka 2019., http://strane.ba/petar-gudelj-ni-jednu-svoju-pjesmunisam-napisao-namjerno/.
} 
propozicijama cent(a)ra, ${ }^{45}$ bilo da ih tražimo u geografsko-povijesnom sloju razvoja Imotske krajine, bilo u osobnim iskustvima ovdje promatranog autora, odnosno životu i stvaranju izvan dominantnih (hrvatskih) književnih središta. Geografija pograničja stoga je simbolična geografija koja opisuje zamišljeni prostor, prostor pamćenja, te se pejzaž pograničja ne mora identificirati s toposom izgubljene Arkadije, iako se neki njegovi rekviziti i aspekti mogu odnositi na navedeni topos. Semantični centar svijeta pograničja koji se evocira kroz takav pejzaž jest konfliktno supostojanje pozicije otvaranja i zatvaranja, sukoba raznih sustava i hijerarhija vrijednosti i neprestano pregledavanje kulturnih odraza, slika, (auto)stereotipova. ${ }^{46}$

U slučaju Imotske krajine zanimljivo je promatrati ispreplitanje geografije krša (stvarnoga pejzaža) i geografije pograničja (simboličnog pejzaža) koji su dvama impulsima autoru da stvara pod utjecajem genius loci. „Duh mjesta“ pritom možemo promatrati kako djeluje na dvjema razinama: prva je odnos između mjesta i promatrača, a druga odnosi među elementima danoga prostora i njegova okruženja. ${ }^{47}$ Odnos promatrača (u ovom slučaju lirskoga subjekta) i mjesta koje se promatra istodobno ovisi o emotivnim i mentalnim stanjima promatrača, ali ga taj odnos na neki način i oslobađa, preispitivanje, prevrednovanje prostora ruši granice koje si je promatrač prethodno postavio. Stoga svrha promatranja nije definiranje, već interogacija. ${ }^{48}$ Konačni odgovor na pitanja koja si lirski subjekt/narator/autor postavlja nazire se u posljednjim zbirkama, u kojima se vidi traženje primirja, spokoja, nakon lutanja, metamorfoza, mitiziranja, i to gotovo terapeutskim povlačenjem u zavičaj: „Još možeš naći kakvu biokovsku spilju s pogledom na otoke i u njoj izlizivati rane, noktom po litici pisati pjesme. ${ }^{\text {(49 }}$

Završno, na razini teme i stila možemo reći da se Gudeljeva poetika potpuno uklapa u obrazac poetike onih (perifernih) regija u kojima usmena književnost ima poseban značaj čak i u vremenu pismenosti. Tu odigrava društvenu i kulturnu ulogu konsolidacije identiteta ${ }^{50}$ te

\footnotetext{
${ }^{45}$ Maria Dąbrowska-Partyka, Literatura pogranicza - pogranicza literatury (Kraków: Wydawnictwo Uniwersytetu Jagiellońskiego, 2004), 10-11.

${ }^{46}$ Dąbrowska-Partyka, Literatura pogranicza, 11.

${ }^{47}$ Tadeusz Sławek, „Genius loci jako doświadczenie. Prolegomena,“ u Genius loci. Studia o człowieku w przestrzeni, ur. Zbigniew Kadłubek (Katowice: Wydawnictwo FA-art, 2007), 15.

${ }^{48}$ Sławek, „Genius loci,“ 26-27.

${ }^{49}$ Gudelj, Duša tilu, 44.

${ }^{50}$ Walter Ong, Oralność i pismienność. Stowo poddane technologii, prev. Józef Japola (Varšava: WUW, 2011), 205.
} 
je usmenost u ovakvoj sredini „uključena u odvijanje društvenoga života. ${ }^{\text {"51 }}$

Govoreći o epskoj poeziji, Solar će reći ono što bi se moglo primijeniti na Gudeljevu poeziju i pjesničku prozu koja

crpi tako svoju građu najvećim dijelom iz mitologije, pri čemu ona izražava postojeća mitska shvaćanja, vjerovanja i mitski organiziran život naroda, ali i stvara vlastite mitološke predodžbe, pa čak i čitav mitski sustav (...) dočarava čitav jedan svijet: ona redovno daje široko zamišljenu i detaljiziranu sliku života nekog naroda. ${ }^{52}$

Ovakva poetska istina ne mora nužno odgovarati stvarnoj, ali je njezina prisutnost na periferiji snažna i prenosi se, među ostalim, i književnim stvaralaštvom. Periferija i poezija jedna se u drugoj ogledaju, jedna drugu produciraju, u dinamičnom, vječno pulsirajućem odnosu.

\section{Marginalizacija}

U kontekstu života na rubu može se reći kako je stvaralaštvo Petra Gudelja nedovoljno prepoznato na hrvatskoj književnoj sceni. Desetljećima se o njemu više pisalo i govorilo u Bosni i Hercegovini te Srbiji, tako je uvršten $u$ desetak antologija poezije i pjesama u prozi, napisano je stotinjak kraćih tekstova o njemu ${ }^{53}$, većinom u Beogradu, ali nedostaju iscrpnije analize ukupnog njegova stvaralaštva te se čini da ga je potrebno potpuno iznova i dublje iščitati. Iako u povijestima hrvatske književnosti nije dobio (dovoljno) mjesta, o njemu piše nekoliko naših književnih povjesničara, posvećujući njegovu stvaralaštvu većinom kraće ulomke. Jelčić ga uvrštava u period postmoderne ističući da je bio „nazočniji u srpskoj nego u hrvatskoj književnoj sredini ${ }^{\text {(54 }}$, Prosperov Novak ${ }^{55}$

\footnotetext{
${ }^{51}$ Malwina Rolka, „Mit i oralność w swietle diagnoz kryzysu kultury nowoczesnej,“ Internetowy Magazyn Filozoficzny Hybris, god. 34 br. 3 (2016): 121, pristupljeno 2. rujna 2019., http://yadda.icm.edu.pl/yadda/element/bwmetal.element.hdl_11089_20127.

${ }_{52}$ Milivoj Solar, Teorija književnosti (Zagreb: Školska knjiga, 2001), 194.

${ }^{53}$ Među ostalima, o njemu su pisali Zoran Kravar, Slavko Leovac, Srba Ignjatović, Adam Puslojić, Vlatko Pavletić, Ivan Lovrenović, Petar Opačić, Miljenko Jergović, Mile Stojić, Enver Kazaz (usp. Jahić, „Strah je magnetno polje“).

${ }_{54}$ Dubravko Jelčić, Povijest hrvatske književnosti (Zagreb: Naklada P.I.P. Pavičić, 1997), 363.

55 Slobodan Prosperov Novak, Povijest hrvatske književnosti, sv. 3 (Split: Marjan tisak, 2004), 246.
} 
daje mu mjesto među suvremenicima naglašavajući da mu je opus „u cjelini zarođen izvan piščeve nacionalne književnosti“, dok ga Milanja uvrštava u skupinu ,izmeđnika“ u kojoj Gudelju uz bok stoje Veselko Koroman, Mirko Rogošić, Anđelko Vuletić, Nikola Martić, Zvonimir Majdak i Alojz Majetić. ${ }^{56}$

Stvaralaštvo Petra Gudelja predstavlja dodatnu vrijednost hrvatske, ali i susjednih književnosti. Samorodnost njegove poetike koja se zasniva uvelike na mitizaciji, na traganju za korijenima, na štovanju tradicije, na izboru tema, mitova i stila koji bi se mogli zvati perifernima - dijelom je razlog nesvrstavanja u hrvatski kanon. Književne je srodnike Gudelju teško naći. Tomislav Dretar navodi pjesnike poput Šimića, Kaštelana i Pešorde koje s Gudeljem spaja dinarski kršs, mediteranska provenijencija te južnoslavenački etnos. ${ }^{57}$ Darko Gašparović podsjeća na bliskost s pjesnicima Mediterana (Kaštelanom, Milićevićem, Pupačićem) ili vršnjakom Vuletićem, a sam autor ukazuje na duhovnu i poetičku bliskost s Ujevićem i Parun. ${ }^{58}$ Petar Opačić primijetit će da bi po dobnoj odrednici Gudelj trebao pripadati krugovašima, ili možda još i više međugeneracijskim pjesnicima, ali više od svih on stoji postrance. ${ }^{59}$

Većina se kritičara slaže da su to uvjetne usporedbe i da je riječ o jedinstvenom pjesničkom glasu. Sorel pak nalazi dva ključna razloga te izmještenosti: izbivanje iz matične kulture (35 godina boravka u Beogradu) te ekskluzivizam zbog „ruralne“ prakse pjesništva, pri čemu urbani diskursi polažu pravo na vrijednosne kriterije u domicilnome kulturnome prostoru. Drugim riječima, hrvatska kultura je centralizirana, pri čemu južnjački pjesnici ne dobivaju jednake prilike kao osta1i. ${ }^{60}$ Gudeljevo dvostruko nepripadanje centru (stvaranje izvan matice i južnjački korijeni) pripisalo je ovome autoru status marginaliziranog mitomana, pri čemu je potrebno naglasiti da „slučaj Petra Gudelja nije problem Petra Gudelja, nego ćudljivosti, nesustavnosti i nazdravičarske prigode govora o književnosti u nas" ${ }^{\text {" }}{ }^{1}$

\footnotetext{
${ }^{56}$ Cvjetko Milanja, Hrvatsko pjesništvo od 1950. do 2000. (Zagreb: Zagrebgraf, 2000), 272.

${ }^{57}$ Vidović Schreiber, Mitski med riječi, 42-43.

${ }^{58}$ Darko Gašparović, „Čitajući Gudelja,“ Croatica: časopis za hrvatski jezik, književnost i kulturu, god. 38, br. 58 (2014): 91-92, pristupljeno 17. ožujka 2019., https://hrcak.srce.hr/130972.

${ }^{59}$ Petar Opačić, „Mit i zbilja Petra Gudelja,“ u Pelazg na mazgi (Zagreb: Školska knjiga, 2004), 594.

${ }^{60}$ Sanjin Sorel, „Tradicijski aspekti pjesništva Petra Gudelja,“ Fluminensia: časopis za filološka istraživanja, god. 25 br. 1 (2013): 76-77, pristupljeno 2. ožujka 2019., https://hrcak. srce.hr/105001.

${ }^{61}$ Krešimir Bagić, Pogled iz Dubrave (Zagreb: Matica hrvatska, 2017), 62.
} 
Sam autor o svojoj marginalizaciji najviše će pisati u knjizi $D u s ̌ a$ tilu (2010) gdje će se uz veliku dozu autoironije osvrnuti na neuvrštavanje u hrvatske antologije ili književna udruženja, odbijanje rukopisa zagrebačkih izdavača, i slično: ${ }^{62}$

Ima te $\mathrm{u}$ četvrtom svesku hrvatske enciklopedije. Trinaest redaka. Tvoji abecedni susjedi: Ganza, Golob, Gorila, Gotovac, govedo, govno, grdobina (hudobina, vrag, vukodlak), guba, Gulin, gusjenica, guska.

Bez slike i s najmanje redaka (mogli bi stati u jednu šaku): ti, Ganza, Gulin i govno.

Činjenica da je autor 2010. nagrađen Goranovim vijencem, zatim 2011. Krležinom nagradom, 2014. plaketom „Dobrojutro more“ te da se o njemu počelo intenzivnije pisati i govoriti u hrvatskim medijima u 21 . stoljeću svjedoči o otvaranju hrvatske književnosti prema autoru kojega će Opačić nazvati živim klasikom, nacionalnim bardom. ${ }^{63}$

\section{Zaključak}

Život na rubu u pjesmama i pjesničkoj prozi Petra Gudelja prikazan je u ovome radu kroz prizmu složenih i burnih odnosa između stvarnog i pjesničkog svijeta koji se u Gudeljevoj poetici isprepliću, nerijetko poistovjećuju. U krškim, usmenim, mitomanskim krajinama uloga je ovakvoga književnika od velikog značaja; on je, kako smo pokazali, (pre)nositelj narodnih predaja, (su)stvaratelj identiteta. S druge strane, društvene i geopolitičke specifičnosti krške periferije pogoduju razvoju poetika poput Gudeljeve te se može zaključiti kako se u njegovu slučaju fikcija i fakcija, periferija i poezija međusobno podupiru, jedna u drugoj ocrtavaju. Naime, prostor Imote, pjesnikova zavičaja kojemu se nakon desetljeća stvaranja fizički vratio, a iz kojeg u stihovima nikad nije ni otišao, pogodan je za hiperboliziranja, metamorfoze, redukcije i ranije navedene tehnike kojima se autor služi. Ipak, Petra Gudelja ne možemo ograničiti na usko određen prostor od Makarske rivijere do granice Imotskoga prema Hercegovini, on to svojom bibliobiografijom nadilazi. Hrvatski su književnici i teoretičari toga postali svjesniji njegovim povratkom u domovinu te preispitivanjem vrijednosnih kriterija hrvatskih

${ }^{62}$ Gudelj, Duša tilu, 152.

${ }^{63}$ Opačić, „Mit i zbilja Petra Gudelja,“ 594. 
praksi pjesništva, pri čemu je odnos centra prema periferiji ključan. Otvorenim ostaje pitanje hoće li se odnos prema „izmeđnicima“ značajnije promijeniti u bližoj budućnosti. Ovaj je rad doprinos mogućem iščitavanju dijela stvaralaštva pjesnika koji je, kako će i on sam i brojni kritičari primijetiti, nakon više od pola stoljeća pisanja ostao površno pročitan i shvaćen.

Odabrani primjeri iz stihova i proze svakako nisu jedini u kojima bi se mogao analizirati koncept života na rubu; razmatranje bi se moglo nastaviti i u drugim smjerovima s primjerima iz iznimno bogatog opusa od 1956. naovamo - od kojih svi svjedoče o autentičnosti imotsko-hrvatsko-ljudskoga pjeva s periferije, o periferiji.

\section{Literatura}

Alaupović-Gjeldum, Dinka. „Običaji životnog ciklusa u Imotskoj krajini i zapadnoj Hercegovini, od konca XIX. stoljeća do Drugog svjetskog rata." Ethnologica Dalmatica, god. 1, br. 8 (1999): 149-168. Pristupljeno 2. rujna 2019. https:// hrcak.srce.hr/108497.

Bagić, Krešimir. Pogled iz Dubrave. Zagreb: Matica hrvatska, 2017.

Ćorić, Šimun Šito. Hercegovci, Hrvati Hercegovine, mitovi, predrasude, zbilja. Zagreb: Pegaz, 1995.

Dąbrowska-Partyka, Maria. Literatura pogranicza - pogranicza literatury. Kraków: Wydawnictwo Uniwersytetu Jagiellońskiego, 2004.

Gašparović, Darko. „Čitajući Gudelja.“ Croatica: časopis za hrvatski jezik, književnost i kulturu, god. 38, br. 58 (2014): 91-100. Pristupljeno 17. ožujka 2019. https://hrcak.srce.hr/130972.

Glibota, Milan. „Prijedlozi o promjeni granica uoči austrougarske okupacije BiH 1878. g.“ Imotske novine, god. 1, br. 1 (2004). Pristupljeno 28. siječnja 2020. http://www.modrojezero.org/docs/history/granice.html.

Grbavac, Jozo. Povijest, vjera i kulturna baština u Imoti. Zagreb: Školska knjiga, 2017.

Grbavac, mr. fra Josip. „Uloga svećenstva Imotske krajine u narodnom preporodu.“

$\mathrm{U}$ Čuvari baštine. Zbornik radova simpozija u prigodi 250. obljetnice prijenosa franjevačkoga samostana u grad Imotski, ur. Marko Babić, Bruno Pezo, 197-228. Imotski: Franjevački samostan; Makarska: Služba Božja, 1989.

Gudelj, Petar. Imotska knjiga. Zagreb: Školska knjiga, 2017.

Gudelj, Petar. Sve što si donio iz planine. Zagreb: Školska knjiga, 2012.

Gudelj, Petar. Duša tilu. Zagreb: V.B.Z., 2010.

Gudelj, Petar. Pelazg na mazgi. Zagreb: Školska knjiga, 2004.

Gudelj, Petar. Moja Imota. Zagreb: Privredni vjesnik, 1991.

„Izvješće o nezaposlenosti i zapošljavanju u 2017. godini u Splitsko-dalmatinskoj županiji.“ Pristupljeno 17. rujna 2019. http://www.hzz.hr/UserDocsImages/ST_ Godisnjak_2017.pdf. 
Jahić, Ervin. „Strah je magnetno polje u kojem drhte sve moje pjesme.“ Poezija časopis pjesničke prakse, god. 8, br. 1-2 (2012): 35-51. Pristupljeno 17. rujna 2019. https://www.ceeol.com/search/article-detail?id=118986.

Jelčić, Dubravko. Povijest hrvatske književnosti. Zagreb: Naklada P.I.P. Pavičić, 1997.

Karanović, Goran. „Petar Gudelj: Nijednu svoju pjesmu nisam napisao namjerno.“ 3. 3. 2015. Pristupljeno 1. siječnja 2019. http://strane.ba/petar-gudelj-ni-jednusvoju-pjesmu-nisam-napisao-namjerno/.

Kutleša, Silvestar. Život $i$ običaji u Imockoj krajini. Imotski: Matica hrvatska; Hrvatska akadamija znanosti i umjetnosti, 1993.

Kužić, Krešimir. Povijest Dalmatinske zagore. Split: Književni krug, 1997.

Lovrenović, Ivan. „Petar Gudelj ili znanje planine.“ Uvod u Pelazg na mazgi. Petar Gudelj, 7-13. Zagreb: Školska knjiga, 2004.

Milanja, Cvjetko. Hrvatsko pjesništvo od 1950. do 2000. Zagreb: Zagrebgraf, 2000.

Nikić, Andrija. „Oslobođenje Imotske krajine od Turaka.“ 16. lipnja 2005. Pristupljeno 1. ožujka 2019. https://povijest.blogspot.com/2005/06/prof-fra-andrijaniki-osloboenje.html.

Nikić, dr. fra Andrija. „Oslobođenje Imotske krajine od Turaka.“ U Čuvari baštine. Zbornik radova simpozija u prigodi 250. obljetnice prijenosa franjevačkoga samostana u grad Imotski, ur. Marko Babić, Bruno Pezo, 173-189. Imotski: Franjevački samostan; Makarska: Služba Božja, 1989.

Ong, Walter. Oralność i pismienność. Stowo poddane technologii. Prevoditelj Józef Japola. Varšava: WUW, 2011.

Opačić, Petar. „Mit i zbilja Petra Gudelja.“ U Pelazg na mazgi. Petar Gudelj, 594-598. Zagreb: Školska knjiga, 2004.

Prosperov Novak, Slobodan. Povijest hrvatske književnosti, sv. 3. Split: Marjan tisak, 2004.

Rolka, Malwina. „Mit i oralność w swietle diagnoz kryzysu kultury nowoczesnej.“ Internetowy Magazyn Filozoficzny Hybris, god. 34 br. 3 (2016): 119-137. Pristupljeno 2. rujna 2019. http://yadda.icm.edu.pl/yadda/element/bwmeta1. element.hdl_11089_20127.

Sławek, Tadeusz. „Genius loci jako doświadczenie. Prolegomena.“ U Genius loci. Studia o człowieku w przestrzeni, ur. Zbigniew Kadłubek, 5-27. Katowice: Wydawnictwo FA-art, 2007.

Solar, Milivoj. Teorija književnosti. Zagreb: Školska knjiga, 2001.

Sorel, Sanjin. „Tradicijski aspekti pjesništva Petra Gudelja.“ Fluminensia: časopis za filološka istraživanja, god. 25, br. 1 (2013): 75-88. Pristupljeno 2. ožujka 2019. https://hrcak.srce.hr/105001.

„Stanovništvo prema vjeri po gradovima/općinama, popis 2011.“ Pristupljeno 17. rujna 2019. https://www.dzs.hr/Hrv_Eng/publication/2012/SI-1469.pdf.

„Stanovništvo staro 10 i više godina prema spolu, a nepismeni i prema starosti, popis 2011.“ Pristupljeno 17. rujna 2019. https://www.dzs.hr/Hrv/censuses/ census2011/results/htm/h01_01_33/H01_01_33.html.

Ujević, Ante. Imotska krajina. Imotski: MH, 1991.

Vidović Schreiber, Tea-Tereza. Mitski med riječi. Split: Hrvatsko kulturno društvo Napredak, 2005. 
Vrčić, fra Vjeko. „Zanimljiv zapis iz starije naše povijesti (Iz ostavštine fra Šimuna Gudelja).“ U Fra Vjekin vijek (zapisi o prošlosti i životu ljudi Imotske krajine), ur. Bože Ujević, 24-27. Imotski: KUD „Ujević“, 2013.

Vrčić, fra Vjeko. „Povijest franjevačkog samostana i crkve svetog Franje u Imotskom.“ U Čuvari baštine. Zbornik radova simpozija u prigodi 250. obljetnice prijenosa franjevačkoga samostana u grad Imotski, ur. Marko Babić, Bruno Pezo, 65-94. Imotski: Franjevački samostan; Makarska: Služba Božja, 1989.

\section{Imota or "Life on the Edge" in Selected Works Written by Petar Gudelj}

Summary: The paper presents the region of Imotska Krajina, or the so-called Imota, as a mythical homeland in selected poetry and prose works by Petar Gudelj. The concept of periphery will be considered, on the one hand, in terms of the geographic position of the mentioned area and its social and political "life on the edge" as well as in terms of its reflection in literary works while, on the other hand, the periphery will be recognized in the long-term Gudelj's marginalization on the Croatian literary scene and in the elements of his poetics; "self-generation," but also relying on tradition and oral literature. The analysis will show how the controversies and the contrast of the karst periphery make a fertile ground for (re)building (literary) identity.

Keywords: Imota, "krajina", identity, oral literature, mythization 